\title{
Comparative Effect of Physical and Chemical Mutagens in Inducing Variability in Gladiolus Variety 'Psittacinus Hybrid'
}

\author{
Dhawani Patel $^{1 *}$, Sudha Patil ${ }^{2}$, Sanket J. More ${ }^{3}$ and Trupti P. Dohiya ${ }^{4}$ \\ ${ }^{1}$ Department of Floriculture and Landscaping Architecture, College of Horticulture, \\ Sardarkrushinagar Dantiwada Agricultural University, \\ Jagudan Mehsana - 382710, Gujarat, India \\ ${ }^{2}$ Department of Floriculture and Landscaping Architecture, ASPEE College of Horticulture \\ and Forestry, Navsari Agricultural University, Navsari- 396 450, Gujarat, India \\ ${ }^{3}$ ICAR-Central Tuber Crops Research Institute, Sreekariyam PO, Thiruvananthapuram, \\ Kerala 695 017, India \\ ${ }^{4}$ Department of Floriculture and Landscaping Architecture, Polytechnic in Agriculture, \\ Junagadh Agricultural University, Dhari -365640, India \\ *Corresponding author
}

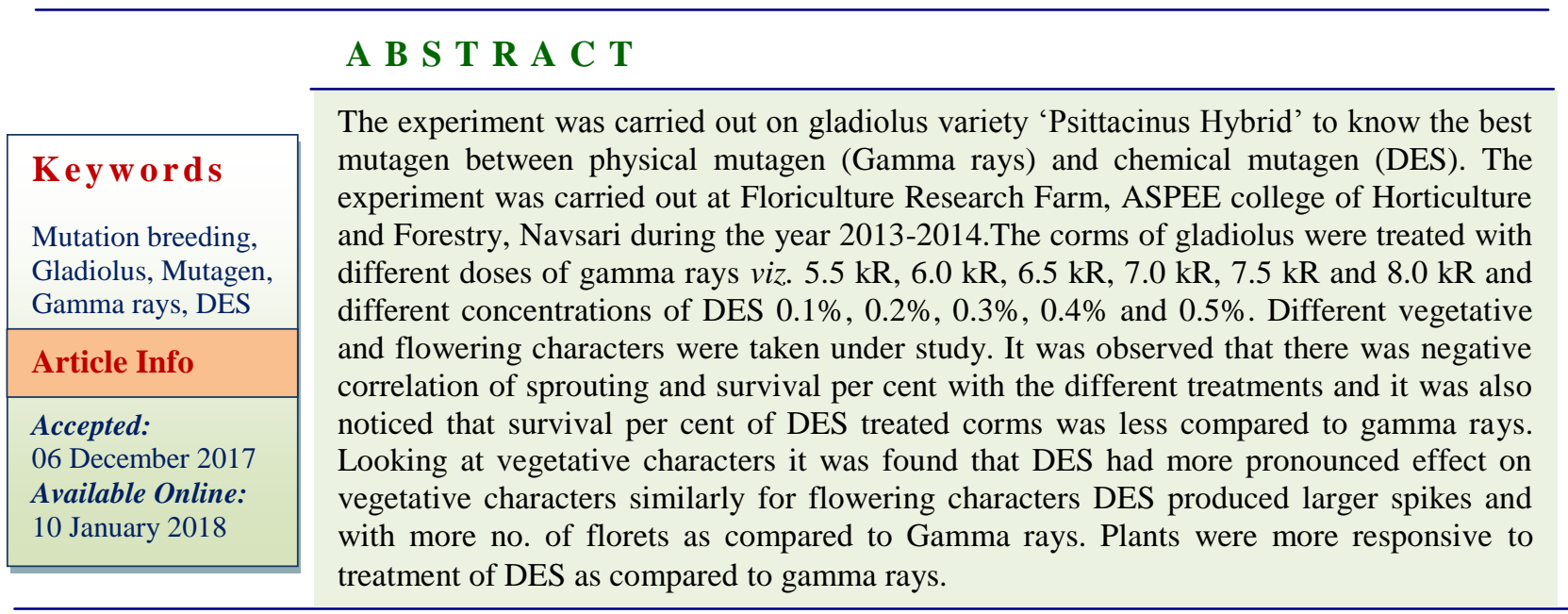

\section{Introduction}

Although induced mutations have great relevance for raising superior plant types in different crop plants, most of the mutations are lethal or semi-lethal and do not have any practical value possibly due to doses monitored or due to the mutagens employed.
Thus to administer successful mutagenesis, selection of efficient mutagens and their treatment doses are pre-requisite as mutagens are potential tools for direct improvement or bringing about certain qualitative and quantitative changes in crop plants. Gladiolus is known worldwide for its attractive spikes and has gained much importance as 'Queen of 
bulbous flowers'. Among the bulbous ornamental plants gladiolus, a member of family Iridaceae and sub family Ixiodeae, is one of the most popular ornamental plants grown commercially for its fascinating flowers in many parts of the world. The demand of gladiolus is increasing therefore, it needs attention towards genetic improvement. Improvement in any crop depends on the natural variability available in it. Breeder's have been resorting to generate variation through artificial hybridization and/or mutation breeding in many ornamental crop and these methods have served the breeders effectively (Singh, 2006).

\section{Materials and Methods}

The present investigation was carried out at Floriculture Research Farm, ASPEE College of Horticulture and Forestry, Navsari Agricultural University during the Rabi season of year 2013-2014. Corms of gladiolus variety 'Psittacinus Hybrid' having diameter of 5-10 $\mathrm{cm}$ were treated with different doses of gamma rays $(5.5,6.0,6.5,7.0,7.5$, and 8.0 $\mathrm{kR})$ and different concentrations of $0.1,0.2$, $0.3,0.4$ and $0.5 \%$ Diethyl Sulphonate (DES) for 3 hours. After the treatment, these corms were immersed in STS solution for 15 minutes and then washed in running tap water for 20 minutes. Then the corms were planted on the raised beds in Randomized Block Design. In each block 40 corms were planted and treatments were replicated thrice.

All the vegetative observations like sprouting percent, survival percent, number of tillers, plant height and leaf area were taken while flowering parameters like days to flowering, spike duration, number of spikes/plant, spike length, rachis length, number of florets/spike and vase life were taken under observation. Thereafter number of corms and cormels, diameter of corms and weight of corms and cormels were observed.

\section{Statistical analysis}

The observed data were statistically analysed by control versus rest method in randomized block design and the significance at $5 \%$ was observed.

\section{Results and Discussion}

The corms of gladiolus were treated with different concentrations of gamma rays and DES and their comparative effect on the vegetative and floral characters is shown in Table 1 and 2 while the effect of mutagens on the corms and cormels parameters is shown in Figure 1.

\section{Vegetative characters}

During the experiment it was found that the corms treated with gamma rays sprouted earlier as compared to DES. Among gamma irradiated corms, application of $5.5 \mathrm{kR}$ gamma rays took the least days (23.40) to sprout while among the DES treatments, the least days (26.20 days) were taken for sprouting when treated with $0.5 \%$ DES. Days to sprouting were increasing with the increasing doses of both gamma rays and DES. The lower doses of mutagens are responsible for stimulating sprouting substances such as enzymes which are set free by irradiation and play an important role in plant metabolic activities resulting in stimulated plant growth. At lower doses, certain plant chemical substances are produced which enhanced sprouting and germination above the optimum level, these chemicals may form certain toxic substances which cause death of the cells. Similarly, sprouting per cent and survival per cent were found to be decreasing with the increasing doses of both gamma rays and DES. But the survival percent of plants treated with gamma rays was more compared to DES. Kapadiya et al., (2014) revealed that chemical mutagens resulted in higher reduction in per cent plant 
survival as compared to the gamma rays. Reduction in survival after exposure to gamma rays was explained due to inactivation and/or decreases in auxin content that affect cell division, it resulting in poor establishment and survival or lethal effect of gamma rays caused due to chromosomal aberration. Looking at the plant height, it was found that the plant height was attained significantly highest $(53.20 \mathrm{~cm})$ with DES at $0.2 \%$ while among the different gamma rays treatment, corms treated with $7.0 \mathrm{kR}$ attained maximum plant height $(48.93 \mathrm{~cm})$. It was clear that getting better plant height DES has more pronounced effect as compared to gamma rays. Archana Bhajantari and Patil (2013) supported the result as they also found increase in height at $0.2 \%$ EMS. But they also noticed reduction in height at lower doses. Plant associated with the biosynthesis of primary metabolic traits may have reduced. Abdullah et al., (2009) said that the increase in the plant height may be due to the reason that certain chemical mutagens produce single base substitutions with different mutation spectra; because of which broad variation occur in morphological parameters as compared to control. He also stated that plant height is quantitative trait which is predominantly controlled by polygenes.

\section{Floral characters}

The mean values of the flowering characters are shown in Table 2. It was observed that the flowering (71.07 days) was found earlier at $5.5 \mathrm{kR}$ as compared to DES and it was significantly least. At $8.0 \mathrm{kR}$, it took maximum days to flowering (104 days). While among the DES treated corms the minimum days to flowering (86.80) was noticed at $0.4 \%$ DES. Delay in flowering due to gamma rays was may be due to the reduction in rate of physiological processes which assists in synthesis of flower inducing substances. Dhakshanamoorthy et al., (2010) and Sudha Patil and Dhaduk (2009) stated that early flowering at lower doses of gamma rays may be because of physiological changes which occur in plant and delayed flowering occur at higher doses due to inhibitory effect.

Ahirwar et al., (2014) reported that flowering was significantly delayed at $30 \mathrm{kR}$ of gamma rays with $0.3 \%$ of EMS mutagens in both the generations as compared to control in Microsperma lentil var. HUL-57. Days to flowering and its duration may be affected as a result of irradiation or mutagenic treatments because many biosynthetic pathways are believed to be altered. Data exposed results in which spike duration was found significantly maximum i.e. 9.66 days at $0.2 \%$ DES which was at par with $0.1 \%$ DES i.e. 8.67 days and $6.0 \mathrm{kR}$ gamma rays i.e. 8.67 days while, the least spike duration i.e. 5.33 days was noticed at $8.0 \mathrm{kR}$ gamma rays.

The data regarding spike length revealed that $0.2 \%$ DES gave significantly highest spike length i.e. $85.13 \mathrm{~cm}$ followed by0.4\% DES i.e. $78.00 \mathrm{~cm}$. High amount of variation in DES is may be because of the chemical mutagens which produce single base substitutions with different mutation spectra due to which broad variation occur in yield parameters as compared to control (Khan et al., 2009).

Moreover, the alkylating agents are highly unstable which are responsible for sudden changes. The minimum spike length (50.73 $\mathrm{cm}$ ) was obtained at $8.0 \mathrm{kR}$ gamma rays. It was also found that the spike length was decreasing with the increasing doses of gamma rays. Reduction in spike length could be because of the reduction of internal auxin production which leads to reduction of growth of plant (Singh et al., 2011). Study also revealed that the number of florets were significantly affected by treatment of mutagenesis and found maximum florets (17.73) in 0.2\% DES which was at par with treatment $\mathrm{T}_{7}$ 0.1\% DES i.e. 16.67 florets (Fig. 2). 
Table.1 Comparative effect of gamma rays and DES on the vegetative characters of gladiolus variety 'Psittacinus Hybrid'

\begin{tabular}{|c|c|c|c|c|}
\hline $\begin{array}{l}\text { Treatment } \\
\text { Details }\end{array}$ & $\begin{array}{l}\text { Days to } \\
\text { sprouting }\end{array}$ & Sprouting per cent & $\begin{array}{l}\text { Survival } \\
\text { per cent }\end{array}$ & $\begin{array}{l}\text { Plant height } \\
\text { (cm) }\end{array}$ \\
\hline $5.5 \mathrm{kR} \gamma$ rays & 23.40 & $10.02(101)$ & $9.94(99.24)$ & 47.87 \\
\hline $6.0 \mathrm{kR} \gamma$ rays & 25.67 & $9.94(99.24)$ & $9.94(99.24)$ & 47.87 \\
\hline $6.5 \mathrm{kR} \gamma$ rays & 30.67 & $9.85(97.52)$ & $9.72(95.04)$ & 44.13 \\
\hline $7.0 \mathrm{kR} \gamma$ rays & 24.40 & 9.85 (97.52) & $9.76(95.76)$ & 48.93 \\
\hline $7.5 \mathrm{kR} \gamma$ rays & 28.13 & $9.51(90.75)$ & $9.51(90.88)$ & 41.87 \\
\hline $8.0 \mathrm{kR} \gamma$ rays & 48.27 & $8.53(73.21)$ & $8.29(69.17)$ & 41.80 \\
\hline $0.1 \%$ DES & 29.07 & $10.02(101)$ & 9.85 (97.52) & 50.20 \\
\hline $0.2 \%$ DES & 26.93 & $9.94(99.24)$ & $9.90(98.57)$ & 53.20 \\
\hline $0.3 \%$ DES & 31.40 & $9.50(90.75)$ & $9.82(96.87)$ & 48.87 \\
\hline $0.4 \%$ DES & 29.73 & $9.49(90.56)$ & $9.28(86.56)$ & 51.53 \\
\hline $0.5 \%$ DES & 26.20 & $9.68(94.26)$ & $9.63(93.29)$ & 52.53 \\
\hline Rest & 29.44 & 9.88 & 9.60 & 48.07 \\
\hline Control & 32.60 & $10.02(101)$ & $10.02(101)$ & 45.87 \\
\hline S.Em. \pm & 1.68 & 0.20 & 0.25 & 2.11 \\
\hline C.D. at $5 \%$ & 4.93 & 0.57 & 0.72 & 6.20 \\
\hline C.V \% & 9.81 & 3.50 & 4.42 & 7.64 \\
\hline
\end{tabular}

Note: Values in parenthesis are retransformed values transformed by square root transformation.

Table.2 Comparative effect of gamma rays and DES on flowering characters of gladiolus variety 'Psittacinus Hybrid'

\begin{tabular}{|c|c|c|c|c|c|c|}
\hline Treatment details & $\begin{array}{l}\text { Days to } \\
\text { flowering }\end{array}$ & $\begin{array}{c}\text { Spike } \\
\text { duration } \\
\text { (days) }\end{array}$ & $\begin{array}{c}\text { Spike } \\
\text { length } \\
(\mathrm{cm})\end{array}$ & $\begin{array}{l}\text { No. of } \\
\text { florets /spike }\end{array}$ & $\begin{array}{l}\text { Vase } \\
\text { life } \\
\text { (days) }\end{array}$ & $\begin{array}{c}\text { Floral } \\
\text { abnormalities (\%) }\end{array}$ \\
\hline $5.5 \mathrm{kR} \gamma$ rays & 71.07 & 8.00 & 65.33 & 12.07 & 8.90 & $0.71(0.99)$ \\
\hline $6.0 \mathrm{kR} \gamma$ rays & 77.33 & 8.67 & 63.60 & 11.67 & 8.38 & $3.03(9.66)$ \\
\hline $6.5 \mathrm{kR} \gamma$ rays & 75.00 & 7.67 & 69.60 & 13.33 & 9.38 & $2.25(5.54)$ \\
\hline $7.0 \mathrm{kR} \gamma$ rays & 83.20 & 6.67 & 58.93 & 11.40 & 9.00 & $0.71(0.99)$ \\
\hline $7.5 \mathrm{kR} \gamma$ rays & 101.27 & 5.67 & 55.80 & 9.93 & 7.50 & $0.71(0.99)$ \\
\hline $8.0 \mathrm{kR} \gamma$ rays & 104.00 & 5.33 & 50.73 & 8.80 & 5.20 & $0.71(0.99)$ \\
\hline $0.1 \%$ DES & 112.60 & 8.67 & 76.13 & 16.67 & 11.26 & $3.58(13.32)$ \\
\hline $0.2 \% \mathrm{DES}$ & 90.53 & 9.67 & 85.13 & 17.73 & 12.26 & $3.52(12.91)$ \\
\hline $0.3 \%$ DES & 87.27 & 7.00 & 67.53 & 12.13 & 9.07 & $2.57(7.164$ \\
\hline $0.4 \%$ DES & 86.80 & 7.67 & 78.00 & 12.53 & 9.08 & $0.71(0.99)$ \\
\hline $0.5 \%$ DES & 88.00 & 6.67 & 73.13 & 15.13 & 10.08 & $2.67(7.63)$ \\
\hline Rest & 88.82 & 7.42 & 67.63 & 12.85 & 9.10 & 1.92 \\
\hline Control & 89.63 & 6.33 & 69.13 & 12.27 & 7.00 & $0.71(0.99)$ \\
\hline S.Em. \pm & 1.53 & 0.53 & 1.19 & 0.43 & 0.49 & 0.08 \\
\hline C.D. at $5 \%$ & 4.49 & 1.55 & 3.50 & 1.26 & 1.43 & 0.22 \\
\hline C.V \% & 2.98 & 12.50 & 3.05 & 5.83 & 9.45 & 7.21 \\
\hline
\end{tabular}

Note: Values in parenthesis are retransformed values transformed by square root transformation. 


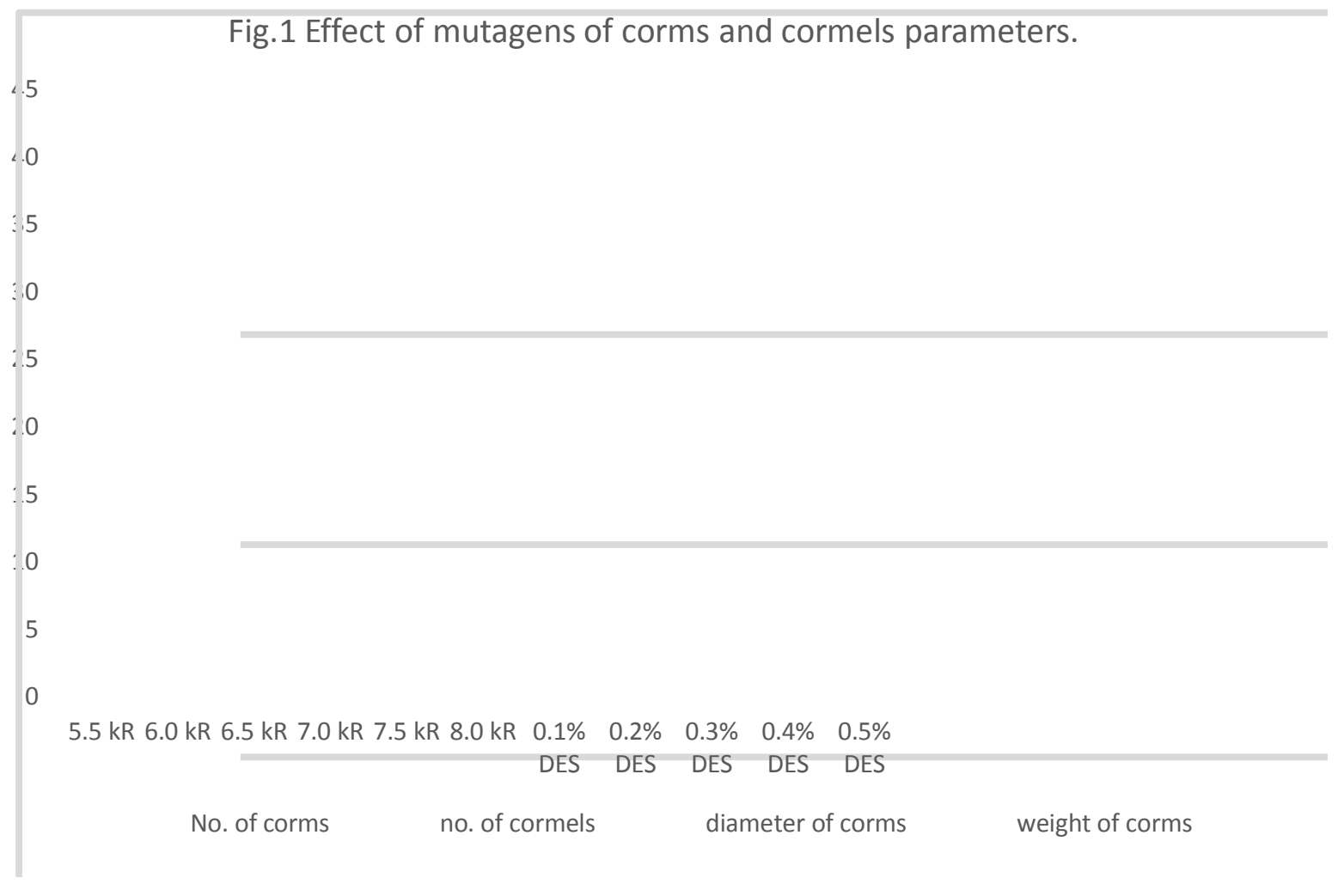

Fig.2 Effect of physical and chemical mutagen on spike length
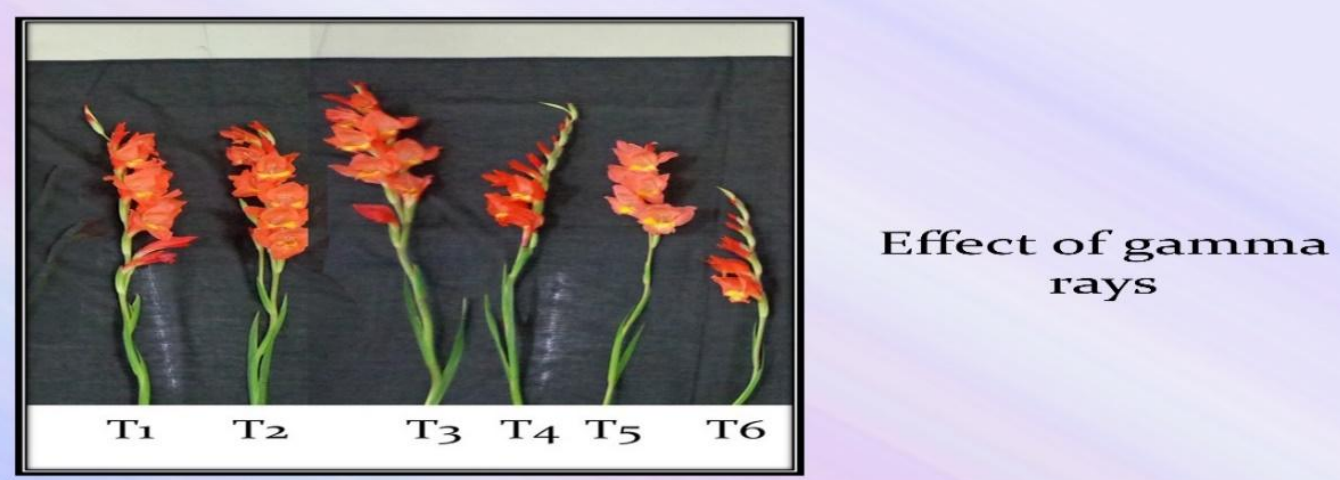

Effect of DES

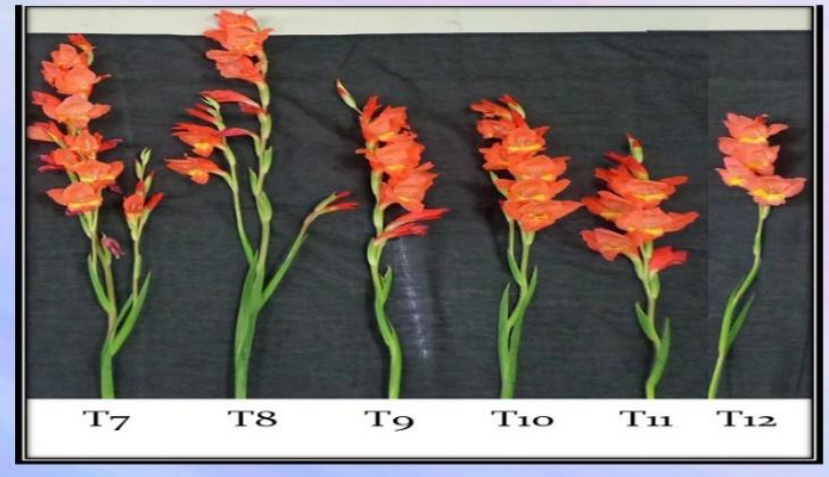


Int.J.Curr.Microbiol.App.Sci (2018) 7(1): 645-652

Fig.3 Different variations observed in flowers

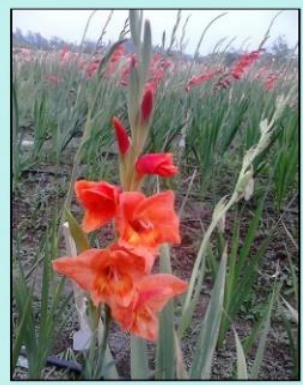

1

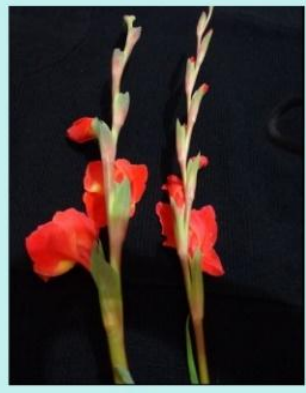

5

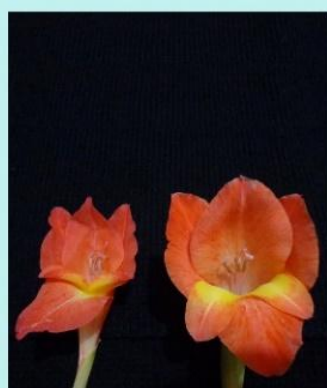

2

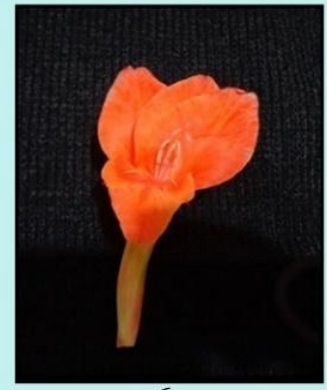

6

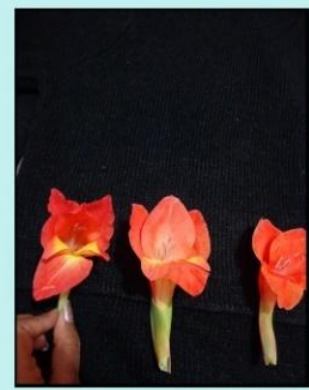

3

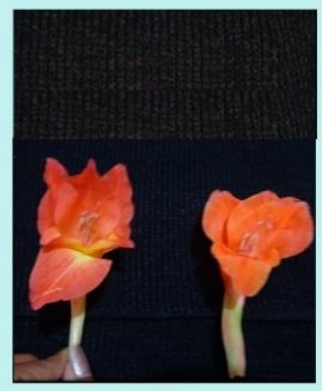

7

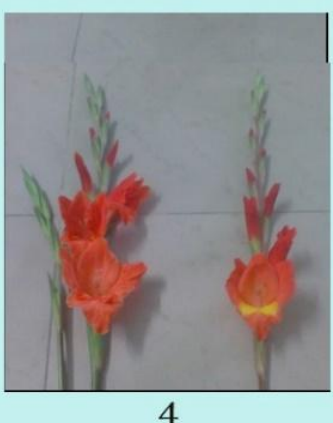

4

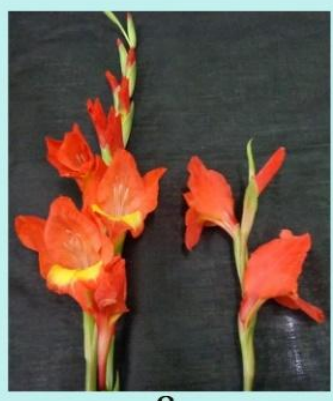

8

Fig.4 Isolated mutants

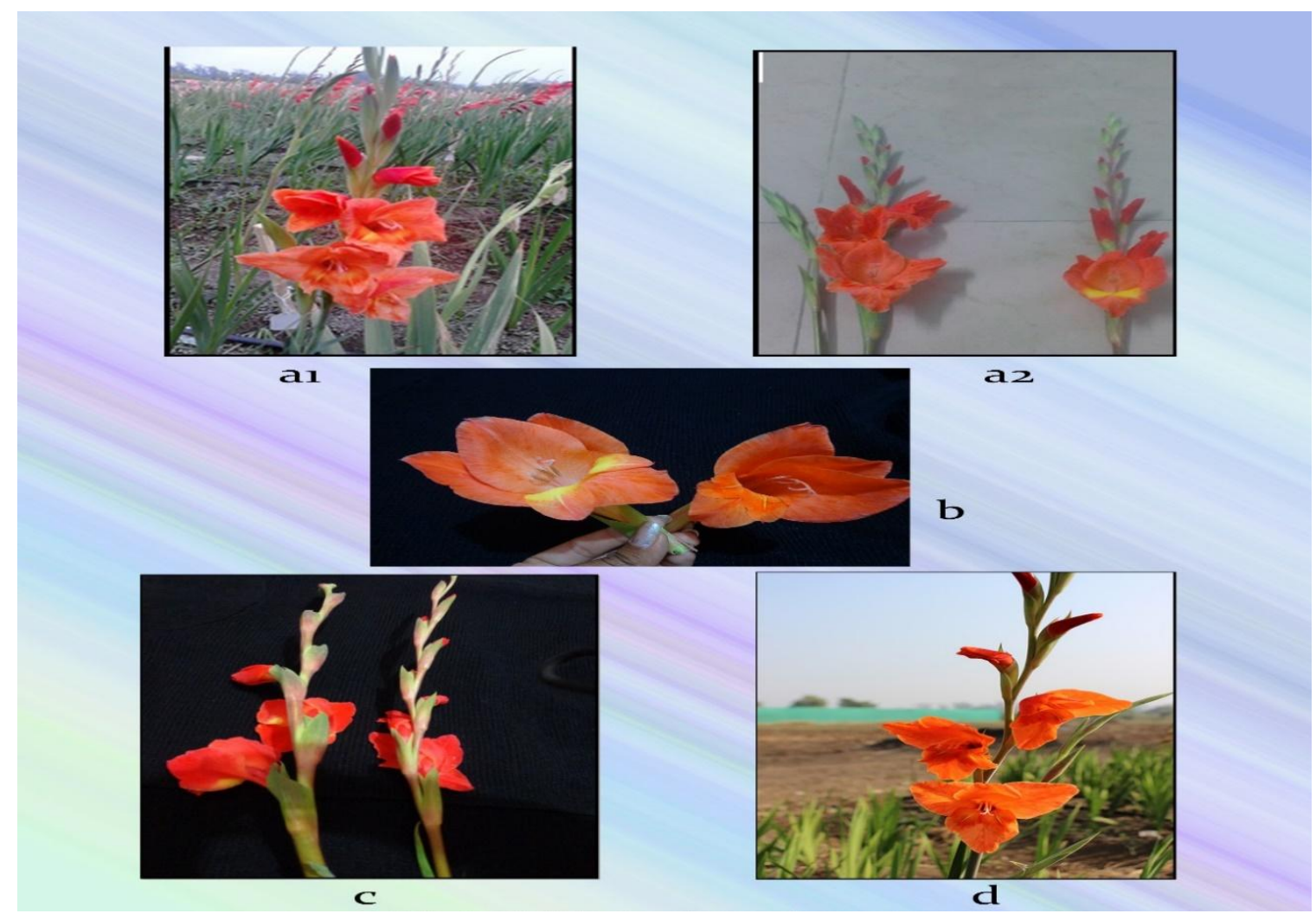


Among the gamma rays, significantly maximum number of florets i.e. 13.33 was found when treated with $6.5 \mathrm{kR}$ gamma rays while the minimum number of florets (8.8) was observed at $8.0 \mathrm{kR}$. The result was supported by Singh et al., (2011) when tuberose was irradiated with gamma rays and Kasumi (2001) supported the findings as his results were parallel to above result where the number of florets decreased by increasing the doses. The number of florets decreased in gamma rays which may be the result of consequences of somatic competition. Flower induction at lower doses was due to mutation in biochemical pathway which assists in synthesis of flower inducing substances leading to formation of flower.

Data revealed that vase life of the flowers with $0.2 \%$ DES was found maximum i.e. 12.26 days which was found at par with $0.1 \%$ DES i.e. 11.26 days. The minimum vase life of 5.20 days was observed at $8.0 \mathrm{kR}$ gamma rays. Moreover, it was revealed that significantly maximum abnormalities $3.58 \%$ were occurred due to treatment $0.1 \%$ DES and that was followed by treatment of $0.2 \%$ DES where $3.52 \%$ abnormalities were recorded. Among the gamma rays, maximum variation i.e. 3.03 per cent was found at 6.0 $\mathrm{kR}$ gamma rays which were followed by 6.5 $\mathrm{kR}$ gamma rays i.e. $2.25 \%$. Bifurcated and trifurcated spikes were observed at $0.1 \%$ DES and $0.2 \%$ DES.

Different mutagens like gamma rays and DES, could significantly influence the various vegetative, flowering and yield parameters and also induced some ornamental variants in gladiolus variety 'Psittacinus hybrid'. Corms treated with DES upto $0.3 \%$ produced different favourable variations and abnormalities. Floral abnormalities were also found when irradiated with gamma rays but not any desirable variation was recorded. Colour novelties were produced with different concentrations of DES. Even the quality of spikes improved due to increased spike length and girth of spike at $0.2 \%$ and $0.3 \%$ DES. Overall, it can be said that DES was more effective as compared to gamma rays for induction of variability.

\section{References}

Abdullah T. E., Endan, J. and Mohd Naz, B. 2009. Changes in flower development, chlorophyll mutation and alteration in plant morphology of Curcuma alismatifolia by gamma irradiation. American. J. Applied Sci., 6 (7): 14361439.

Ahirwar R. N., Lal, J. P. and Singh, P. 2014. Gamma-rays and ethyl methane sulphonate induced mutation in microsperma lentil (Lens culinaris L. Medikus). The Bioscan. 9(2): 691-695.

Archana Bhajantri and Patil, V. S. 2013. Studies on Ethyl Methane Sulfonate (EMS) induced mutations for enhancing variability of gladiolus varieties (Gladiolus hybridus Hort.) in $\mathrm{M}_{1} \mathrm{~V}_{2}$ generation. Karnataka J. Agric.Sci., 26(3): 403-407.

Dhakshanamoorthy, D., Selvaraj, R. and Chidambaram, A. 2010. Physical and chemical mutagenesis in Jatropha curcas L. to induce variability in seed germination, growth and yeild traits. Rom. J. Biol.-Plant Biol., 55(2): 113125.

Kapadiya, D. B.; Chawala, S. L.; Patel, A. I. and Ahlawat, T. R. 2014. Exploitation of variability through mutagenesis (Chrysanthemum morifolium Ramat.) var. Maghi. The Bioscan, 9(4): 17991804.

Kasumi, M. 2001. Studies on induction of flower colour mutants in gladiolus (Gladiolusx grandifloraHort.) by gamma irradiation and tissue culture, Bulletin of the PlantBiotech., 4: 1-49. 
Khan, S., Qurainy, F. A. and Firoz Anwar 2009. Sodium Azide: a chemical mutagen for exhibited a decline. This shows that a saturation point enhancement of agronomic traits of crop plants. Int. J. Sci. Tech., 4: 1-21.

Singh, R., Goyal, R. K. and Godara, A. K. 2011. Effect of gamma radiation on growth, flowering and bulb production in tuberose (Polianthes tuberosa L.) cv. Double. Haryana J. Hort. Sci., 40(3\&4): 128-130.

Sudha Patil and Dhaduk, B. K. 2009. Effect of gamma radiation on vegetative and floral characters of commercial varieties of gladiolus (Gladiolus hybrida L.) J. Ornam. Hort., 12(4): 232-238.

\section{How to cite this article:}

Dhawani Patel, Sudha Patil, Sanket J. More and Trupti P. Dohiya. 2018. Comparative Effect of Physical and Chemical Mutagens in Inducing Variability in Gladiolus Variety 'Psittacinus Hybrid'. Int.J.Curr.Microbiol.App.Sci. 7(01): 645-652. doi: https://doi.org/10.20546/ijcmas.2018.701.078 